
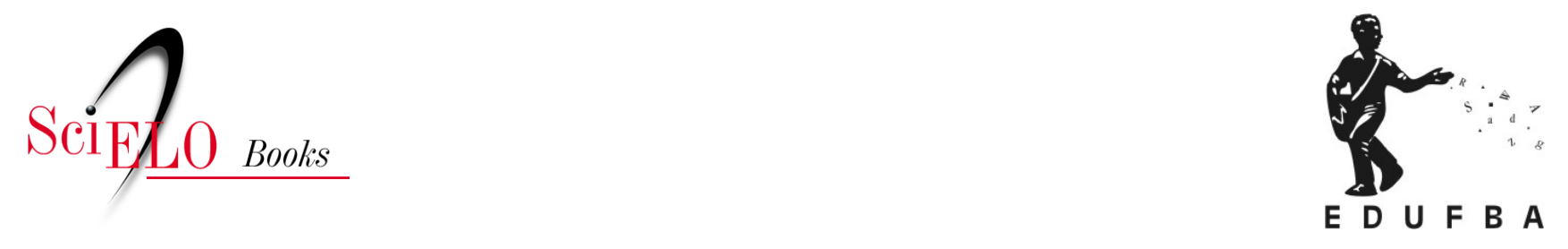

\title{
Fluoretação do sal de cozinha e movimento anti-flúor
}

\author{
Thais Regis Aranha Rossi
}

\section{SciELO Books / SciELO Livros / SciELO Libros}

ROSSI, T.R.A. Fluoretação do sal de cozinha e movimento anti-flúor. In: Produção social das políticas de saúde bucal no Brasil [online]. Salvador: EDUFBA, 2018, pp. 123-154. ISBN 978-85-232-2022-8. https://doi.org/10.7476/9788523220228.0007.

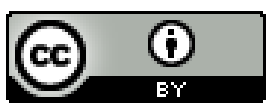

All the contents of this work, except where otherwise noted, is licensed under a Creative Commons Attribution 4.0 International license.

Todo o conteúdo deste trabalho, exceto quando houver ressalva, é publicado sob a licença Creative Commons Atribição 4.0. 


\section{FLUORETAÇÃO DO SAL DE COZINHA E MOVIMENTO ANTI-FLÚOR}

No início de 1990, conforme ressaltado anteriormente, em virtude do novo governo federal recém-eleito, ocorreu uma reorganização dos Ministérios, sendo que a DNSB passou a integrar a Secretaria Nacional de Assistência à Saúde que ficou responsável, dentre outras funções, por:

[...] elaborar e promover a execução de programas nacionais noscampos de saúde materno-infantil, saúde bucal, saúde mental, nutrição, doenças crônico-degenerativas, sangue e hemoderivados, assistência à pneumologia e dermatologia sanitárias, doenças sexualmente transmissíveis e aids. (BRASIL, 1990a)

Analisando-se as tomadas de posição, a Aboprev divulgava amplamente sua adesão e opção pelo método de fluoretação das águas, informando que o flúor na água pode prevenir cárie em todas as idades. A matéria "Água com flúor previne cáries em todas as idades" publicada no jornal Folha de São Paulo, de 29 de janeiro de 1990, tratou também dos mecanismos da ação do flúor na prevenção da cárie dentária.

Países como a Suíça (desde 1955), Colômbia (desde 1965), Hungria (desde 1966-1972), Colômbia (desde 1972), Áustria (desde 1982), Guatemala (desde 1986), Costa Rica (desde 1987), Jamaica (desde 1987), Peru (desde 1990) e Uruguai (desde 1990) apresentavam experiências exitosas do uso do sal fluoretado como medida sistêmica de combate à cárie, segundo a OPAS e entrevistados. No início da década de 1990, a política da fluoretação sistêmica através do sal de cozinha começou a ser formulada no Brasil, por influência do órgão internacional, que se posicionava a favor deste método. 
Matérias da mídia impressa abordavam a política de fluoretação do sal nas regiões Norte e Nordeste, nos locais onde não existiam estações de tratamento. Na publicação, Sergio Weyne defendia o método de fluoretação das águas como mais adequado à realidade brasileira. (MINISTÉRIO..., 1990)

Em 1990, foi editada uma Portaria, assinada pelo ministro Alceni Guerra, que criava o "Programa Nacional de Controle da Cárie Dentária”. A Portaria n 1.437, de 14 de dezembro de 1990, publicada no DOU, em 17 de dezembro de 1990, justificava a criação do Programa devido ao fato de que o "método coletivo de prevenção presentemente adotado de abastecimento de água fluoretada não oferece uma cobertura populacional com a abrangência requerida para reverter a prevalência dessa doença”. (BRASIL, 1990d, p. 2434)

Em 5 de fevereiro de 1991, através da Portaria $n^{\circ}$ 1, publicada no DOU, de 6 de fevereiro de 1991, assinada pelo presidente do INAN, Marcos de Carvalho Candau, ${ }^{63}$ e pelo diretor da DNSB, Sérgio de Carvalho Weyne, foi criada a Coordenadoria Geral do Programa Nacional de Controle da Cárie Dentária pelo método de fluoretação do sal.

As atribuições da referida coordenadoria eram:

- "responsabilizar-se pela implantação, execução, acompanhamento e avaliação do Programa Nacional de Controle da Cárie Dentária pelo método de fluoretação do sal";

- "por atos próprios, designar os componentes da estrutura organizacional do Programa e ainda outros atos”, de acordo com a primeira portaria publicada;

- "organizar, a cada ano, em datas regulamentares, a proposta orçamentária do Programa para o ano seguinte"; e

- “indicar ao Ministério da Saúde os componentes do Grupo Técnico Consultivo".

Alguns professores e pesquisadores da Universidade Estadual do Rio de Janeiro (UERJ), como o Hélio Wanderley Uchoa, da Rede Cedros, e da UFRJ, o Mário Chaves, eram favoráveis ao método da fluoretação do sal. A Rede Cedros foi criada em 1989 com o apoio financeiro da Fundação W. K. Kellog, sendo seu secretariado executivo localizado no Centro Colaborador para Pesquisas e Promoção de Saúde Bucal da OMS e da Faculdade de Odontologia da UFRJ. Tinha como meta "constituir-se em um elo unindo a profissão odontológica, representada por suas

Marcos de Carvalho Candau, sociólogo, então presidente do INAN. 
associações de classe, instituições de serviços e de educação, dedicadas ao ensino a pesquisa”. (CEDROS, 1998) Também buscava estreitar a relação entre o Brasil e outros países da América Latina, além de "estimular e facilitar projetos que envolvam universidades, serviços públicos e instituições privadas”. A coordenação era exercida por Roberto Vianna, Mário Chaves, Eymar Sampaio e Thomaz Chianca. Existiam sete grupos de trabalho, ressaltando-se três dentre estes:

- métodos de massa/fluoretação do sal, coordenado por Hélio Uchoa;

- Métodos de massa/fluoretação das águas, coordenado por Paulo Capel Narvai;

- Saúde Bucal nos SILOS, com coordenação de Sylvio Gevaerd. (CEDROS, 1998)

A Rede Cedros foi responsável pelo Projeto UNI, ${ }^{64}$ uma estratégia da Fundação Kellog de atuar no desenvolvimento de modelos de serviços locais de saúde, formação e capacitação de recursos humanos e de participação comunitária. (BOLETIM INFORMATIVO, 1993) Tanto o Mário Chaves, como o Hélio Uchoa haviam participado da FSESP que conduzira programas de fluoretação das águas em Baixo Guandú (ES) e Aimorés (MG), em 1953. Esse projeto teve resultados muito positivos que inspiraram os estados e os municípios a realizarem a fluoretação das águas de abastecimento público e aplicações tópicas em escolares como método de prevenção da cárie dentária. Entretanto, uma análise de quase 40 anos após a implantação do programa levou os pesquisadores a observar alguns problemas:

- limitação da implantação da fluoretação das águas de abastecimento pelos estados;

- constantes interrupções dos programas implantados decorrentes de problemas políticos;

64 Projeto UNI é a abreviação de "Uma nova iniciativa na formação dos profissionais de saúde: união com a comunidade". Os Projetos UNI foram desenvolvidos em países da América Latina, a partir da década de 1990, tendo sido financiados pelo Fundação W. K. Kellog. Buscavam atuar no desenvolvimento e nas relações entre universidade, sistema local de saúde e comunidade. Seus objetivos eram: (i) promover os movimentos de progresso sincrônico na educação, na prestação de serviços de saúde e na comunidade; (ii) criar e difundir modelos passiviveis de replicação referentes a estes três campos; (iii) apoiar modelos de Integração Docente Assistencial no âmbito do Sistema Local de Saúde, baseados no trabalho interdisciplinar e multiprofissional e na inovação de métodos pedagógicos; (iv) promover o aprimoramento da formação profissional dos graduandos na área de saúde, adequando-os à futura prática profissional e às necessidades de saúde da comunidade; (v) promover a participação comunitária nas decisões relativas ao setor de saúde; (vi) apoiar o desenvolvimento de lideranças na universidade, nos Serviços de Saúde e na Comunidade.(MACHADO; CALDAS JR; BORTONCELLO, 1997) 
- controle da dosagem do flúor, como a sub-dosagem; e

- paralisação de vários programas. (UCHOA, 2015)

Levando em consideração a análise realizada, o grupo de trabalho do método de massa para prevenção da cárie dentária através da fluoretação do sal de cozinha da Rede para Cooperação em Estudos e Desenvolvimento de Recursos Odontológicos para o Setor Saúde (Rede Cedros), passou a estudar a viabilidade de desenvolver um estudo visando definir a utilização do flúor no sal de cozinha, considerando como pressupostos:

- sua universalidade, pois o método de fluoretação do sal de cozinha iria cobrir significativa parcela da população dos centros urbanos e da zona rural, independentemente da sua condição socioeconômica, educacional ou idade, tendo em vista que todos consomem sal de cozinha, o que não ocorre, necessariamente, com a fluoretação dos sistemas de abastecimento d'água, limitado às pessoas que tem acesso à rede de distribuição e quase sempre, não atingindo os moradores da zona rural;

- o controle da dosagem do flúor no sal de cozinha, que seria realizado em apenas 12 refinarias que processavam o sal, cobrindo, aproximadamente, 80\% da população; no caso da fluoretação das águas, o controle da dosagem do flúor exigiria a organização de um sistema de vigilância bastante complexo em mais de 5 mil municípios;

- o custo, pois acreditava-se que dos métodos de prevenção da cárie dentária, a fluoretação do sal seria o menos dispendioso.Na época, segundo estimativa feita na França, o custo per capita com a operacionalização do método ficaria em US $\$ 0,02$, muito inferior ao demais métodos. Devendo-se destacar, ainda, que a fluoretação do sal seria de "custo zero" para os cofres públicos, tendo em vista que as empresas se adequariam às normas fornecendo os insumos; $\mathrm{e}$

- democratização pois o uso do sal de cozinha com flúor não seria compulsório, podendo a comercialização ser feita através do sal de cozinha com e sem flúor. (CHAVES, 1991; UCHOA, 2015)

Em seguida, o Mário Chaves se reuniu com o Marcos Candau, em 25 de janeiro de 1991, e com o presidente do INAN para discutir as bases de elaboração de um Convênio INAN - Ministério da Saúde com a Fundação Universitária José Bonifácio (FUJB)/UFRJ. 
O memorando enviado por Chaves ao presidente do INAN destaca a importância da cooperação entre a Rede Cedros e o Instituto para a implementação da fluoretação do sal nas três macrorregiões do Brasil assim como referia que o prof. Hélio Uchoa já dispunha de contatos em municípios e a necessidade de "um intercâmbio constante entre o projeto de apoio técnico-científico ao INAN no Rio de Janeiro e a Coordenação Geral e Executiva em Brasília, incluindo também o relacionamento com a Divisão Nacional de Saúde Bucal”. (CHAVES, 1991, p. 1) A pactuação da política foi uma confluência de interesses de agentes dos campos burocrático, científico e político.

Foi selecionado o município de Cabo Frio para a implantação do Projeto de Fluoretação do Sal de Cozinha, tendo em vista o interesse do prefeito, Ivo Saldanha, médico, que, como deputado estadual, já havia conseguido introduzir o Artigo 292 na Constituição do estado do Rio de Janeiro estabelecendo a produção do sal fluoretado. O Decreto Municipal n 1.721/1990 da prefeitura de Cabo Frio determinava à Secretaria de Saúde e Ação Social, fixar a dosagem de flúor a ser adicionada ao cloreto de sódio pela indústria produtora de sal no município. (SALDANHA et al., 1992)

As normas técnicas caracterizavam a cárie como um grave problema de saúde pública com alta prevalência e incidência, além de apontar que a fluoretação das águas não oferecia uma cobertura populacional com a "abrangência requerida para efetivamente reverter essa doença”, tendo em vista que sua expansão no país ocorreu de forma desigual sendo o maior progresso constatado nas regiões Sul e Sudeste, em detrimento das outras. Além disso, a fluoretação do sal poderia alcançar áreas não servidas por estações de tratamento de água. Neste sentido, o Ministério da Saúde definia a fluoretação do sal como um método complementar de prevenção da cárie em localidades não beneficiadas pela água fluoretada. (BRASIL, 1991c)

A execução do Programa ficou a cargo do INAN e da Fundação Nacional de Saúde que poderia manter convênios com órgãos nacionais e internacionais para este fim. Em 28 de fevereiro de 1991, foi editada a Portaria $\mathrm{n}^{\circ} 2$ do INAN que aprovava as Normas Técnicas para o desenvolvimento do Programa Nacional de Controle da Cárie Dentária, pelo método da fluoretação do sal. (BRASIL, 1991c)

A Portaria determinava um levantamento da situação da fluoretação das águas de abastecimento no Brasil, a fim de delimitar áreas de exclusão para o sal de cozinha. Fixou, também, que o produto a ser utilizado no sal seria o fluoreto de potássio em solução, com a dosagem de $250 \mathrm{mg}$ por quilo de sal, podendo variar entre 225 e $275 \mathrm{mg}$. (BRASIL, 1991c) 
Em termos operacionais, o Programa seria iniciado nas refinarias com infraestrutura adequada, estendendo-se, progressivamente, às outras. O INAN iria adquirir o fluoreto de potássio e a Fundação Nacional de Saúde o distribuiria às indústrias beneficiadoras de sal. As embalagens conteriam uma etiqueta verde com a expressão "sal fluorado" e a legenda "Este produto somente poderá ser consumido em localidades onde o teor de flúor na água de abastecimento for igual ou menor que meio miligrama por litro”. Por fim, as empresas seriam responsáveis por distribuir o produto nos locais que não se constituíssem zonas de exclusão definidas pelo Ministério da Saúde com base nos sistemas de abastecimento de água. Como mecanismos de acompanhamento, estabeleceu-se que a Fundação efetuaria a entrega do insumo, faria o monitoramento e prestaria assistência técnica. Cada indústria receberia o material de coleta de amostras que deveriam ser analisadas em laboratórios próprios. Os técnicos da Fundação Nacional de Saúde recolheriam, diariamente, as amostras, coletadas a cada 60 minutos pela empresa, para validação dos resultados obtidos pelos laboratórios das indústrias. O controle do sal fluoretado seria inicialmente implantado nos estados do Rio Grande do Norte, Rio de Janeiro, Ceará e Espírito Santo. (BRASIL, 1991c) Quanto à avaliação do Programa, coube à DNSB interpretar os resultados, realizar inquéritos epidemiológicos dos níveis de cárie e quanto à fluorose nas populações com sal fluorado. (BRASIL, 1991c)

Aproximadamente dois meses após o lançamento do Programa, aparecia na mídia certa divisão de opiniões entre profissionais e gestores. (USO..., 1991) As Secretarias Municipal e a Estadual de Saúde de São Paulo manifestaram repúdio à fluoretação do sal. O cirurgião-dentista Marco Manfredini, assessor de saúde bucal da Secretaria Municipal de Saúde de São Paulo, apontava a inexistência de um estudo piloto assim como o alto valor do produto. Já Pedro Martinelli, presidente da ABO elogiava o Programa.

A Aboprev noticiou o fato afirmando que o Programa deveria estar implementado até o dia 30 de junho, além dos integrantes do Grupo Técnico Consultivo para supervisão da política composto por Alfredo Reis Viegas, Rui Oppermann, Marisa Maltz e Jayme Aparecido Cury. (PROGRAMA..., 1991) Sérgio Weyne ratificava que a nova ação beneficiaria de 89 a 90\% da população mais desassistida, pela obrigatoriedade da venda do sal fluoretado nos locais sem água fluoretada. (PROGRAMA..., 1991) Outro anúncio foi a divulgação do lançamento do Programa e de outras ações pelo Ministério da Saúde, em parceria com a Aboprev e a empresa Colgate em programa de televisão da rede Bandeirantes. (NO DIA..., 1991) 
A empresa Colgate foi parceira da Aboprev em alguns eventos. A vertente defendida pela Associação ia ao encontro dos interesses daquela indústria.

Ainda em 13 de agosto de 1991, foi firmado convênio entre a prefeitura de Cabo Frio e a UERJ visando o desenvolvimento de estudos epidemiológicos para acompanhamento da fluoretação do sal. No ano seguinte, Sérgio de Carvalho Weyne foi exonerado do cargo de diretor do Departamento de Programas de Saúde, em 21 de janeiro de 1992, passando a ser nomeado como secretário nacional de Vigilância Sanitária do Ministério da Saúde. O dentista Mércio de Azevedo Ferreira assumiu, temporariamente, a gestão da DNSB. (BRASIL, 1992c)

Em Cabo Frio, deu-se seguimento às medidas de fluoretação do sal através do Decreto Municipal n 1.796/1992 que definia normas para a implantação do Programa Municipal, em convênio com a UERJ. Em abril de 1992, iniciou-se a realização de estudo epidemiológico ${ }^{65}$ visando determinar a prevalência dos problemas de saúde bucal (cárie dentária, periodontopatias, má-oclusão, fluorose) em crianças de 6 a 14 anos de idade, além de determinar a taxa de excreção de flúor pela urina em uma amostra da população do município de Cabo Frio e o teor de flúor nas fontes de abastecimento de água do município.

A empresa salineira Perynas conseguiu a aprovação do registro de dois produtos: o sal fluorado refinado e iodado, Biosal; e o sal fluorado refinado extra iodado, MOC, através da Portaria ${ }^{\circ} 110$, de 26 de agosto de 1992, publicada no DOU, em 28 de agosto de 1992. A direção da Companhia Salinas Perynas com o propósito de atender ao Decreto Municipal n 1796/1992 de Cabo Frio comunicou à Divisão de Produtos (Diprod), da Secretaria Nacional de Vigilância Sanitária do Ministério da Saúde que, a partir de 18 de junho de 1992, estaria fornecendo ao mercado consumidor de Cabo Frio, o sal fluorado, tendo recebido a aprovação do registro definitivo. (SALDANHA et al., 1992) Cabo Frio passou a utilizar o sal fluoretado produzido pela Companhia Salinas Perynas. O prefeito e os pesquisadores organizaram uma publicação sobre o histórico da fluoretação do sal em Cabo Frio, desde o Gecahy, um sal colhido nas margens da lagoa Araruama e pilado com pimenta, utilizado

65 Participaram do estudo epidemiológico: Helio Wanderley Uchôa, prof. titular de Odontologia Social da FOUERJ, como coordenador; Eymar Sampaio Lopes, prof. titular de Odontologia Social da FOBauru (SP); Luiz Octávio Coelho Guimarães, prof. titular de Odontologia Social da Faculdade de Higiene e Saúde Pública da USP; Maria Lucilda Tavares de Mello, profa ${ }^{\text {. ad- }}$ junta de Odontologia Social da FOUERJ; Francisco de Assis Ramos de Souza, coordenador de Odontologia da Secretaria Municipal de Saúde e Ação Social da Prefeitura Municipal de Cabo Frio; João Baptista Gonçalves, prof. adjunto de Odontologia Social da FO da Universidade Federal de Goiás (UFGO); Wilkens Oliveira de Souza, assistente de Coordenação de Saúde Oral da Fundação Nacional de Saúde (MS); e Thomaz Chianca, secretário executivo da Rede Cedros. 
como tempero, até o sal fluoretado. Também foi abordado o convênio com a FOUERJ e as ações desenvolvidas pela gestão para este fim.

No nível municipal, a implantação oficial do Programa Fluoretação do Sal em Cabo Frio (RJ) foi celebrada com a presença dos presidentes dos Conselhos Regionais de Odontologia (CRO) de São Paulo e do Rio de Janeiro, ABO Nacional, ABO/ RJ, APCD, docentes da UERJ, UFRJ e USP, membros da Rede Cedros, prefeito de Cabo Frio e de vários municípios do estado, diretores e funcionários da Cia. Salinas Perynas. (ABORJ, 1993; CHAVES, 1992; UCHOA, 2015)

Jornais das associações de classe como a ABO nacional e do Rio de Janeiro, assim como a Rede Cedros, através de um editorial escrito por Mário de Magalhães Chaves, expressaram apreciação ao movimento de fluoretação do sal nos municípios, atribuindo grande esperança de redução dos índices de cárie na população brasileira. Chaves (1992) citou a conformação de dois grupos do campo odontológico que se opunham um ao outro, o dos defensores da fluoretação das águas e o dos defensores da fluoretação do sal. Atribuindo o sucesso ao bom senso, explicou a mudança de estratégia que deslocou o eixo de decisão do nível central para o periférico.

Iniciada com uma citação de Pitágoras que afirma que o sal é nascido dos mais puros pais: o sol e o mar, ${ }^{66}$ publicação da Organização Panamericana da Saúde (OPAS) traz histórico de sucesso da fluoretação do sal, além de preconizar como planejar e implementar um programa de fluoretação do sal. (PAHO, 2005)

Os autores apontam que este método vem sendo conduzido há mais de meio século na Europa e nas Américas, tendo sido desenvolvido à semelhança da adição de iodo no sal de cozinha para prevenção de doenças ocasionadas pela supressão desse nutriente. (PAHO, 2005) Os métodos de fluoretação do sal e de fluoretação das águas são modos de aplicação sistêmicos do flúor cuja associação é contraindicada (EIDELWEIN, 2010) ao passo que é possível combinar métodos de uso tópico e sistêmico, como a utilização de dentifrícios fluoretados com a água ou o sal. O uso dos dentifrícios também é recomendado para países com baixa prevalência de cárie, já os métodos sistêmicos são indicados para aqueles países com elevada ou moderada prevalência da doença. (EIDELWEIN, 2010) Criticando a fluoretação do sal, Neder ${ }^{67}$ e Manfredini ${ }^{68}$ (1991) apontaram uma obsessão do governo Collor por

66 Tradução livre feita pela autora. Fragmento original: "Salt is born of the purest of parents: the sun and the sea" Pythagoras. (PAHO, 2005).

67 Carlos Neder, médico formado pela USP, mestre em Saúde Pública pela Unicamp, vereador na Câmara Municipal de São Paulo, por quatro mandatos, e deputado estadual do estado.

68 Marco Antonio Manfredini é dentista, mestre em Ciências, doutor pela FSP/USP. Integrou o MBRO, foi coordenador Municipal de Saúde Bucal em São Paulo (1989-1991) e Santos 
“modernidade" e pela inclusão do Brasil no primeiro mundo, o que poderia ter um custo alto ao país.

Comentaram a ausência de discussões técnico-científicas e a perplexidade dos gestores e profissionais do setor nos estados ao tomarem conhecimento da Portaria que instituía o Programa de fluoretação através do sal de cozinha, tendo em vista a existência da Lei n 6050/1974 que instituía a fluoretação das águas, com a mesma finalidade de combate à cárie com método sistêmico.

Os autores apontaram que a fluoretação das águas beneficiava cerca de 66 milhões de pessoas à época, com um custo baixo, justificando que o país era autossuficiente na produção dos insumos necessários e a fluoretação do sal de cozinha exigiria importação do fluoreto de potássio de um único produtor alemão. Ademais, o trabalho cita as políticas empreendidas e todo o investimento realizado (NEDER; MANFREDINI, 1991), já referidos anteriormente, pelo método sistêmico utilizando a água que também envolveram o INAN, a FSESP, o Ministério da Saúde e o IPEA.

Esse ponto de vista mostrava também que, naquelas comunidades onde havia água fluoretada, existia redução nos indicadores de cárie e a necessidade de controle efetivo não ocasionava um defeito quanto ao método em si. Ademais, citaram que a fluoretação das águas estava implantada em cerca de 50 países, como os Estados Unidos e a União Soviética. Por fim, argumentaram que o país não definia uma política nacional de saúde bucal democrática para ser seguida em todo o território, apontando para políticas anteriores efêmeras, como o Precad e o Programa Nacional de Controle da Cárie Dentária com uso de Selantes e Flúor (PNCCSF) assim como a necessidade de discussão ampliada sobre o tema. (NEDER; MANFREDINI, 1991)

Os agentes do campo burocrático buscaram sustentação para a política no campo legislativo. Existem cinco ocorrências de atos legislativos no período de 1990 a 1993 na Câmara dos Deputados do Brasil, sendo dois projetos de lei (PL), dois requerimentos de informação e uma identificação da proposição.

Em 1991, dois requerimentos de informação foram submetidos pelo então deputado federal Eduardo Jorge ${ }^{69}$ do Partidos dos Trabalhadores (PT) de São Paulo ao ministro Alceni Guerra sobre a fluoretação do sal de cozinha e solicitando esclarecimentos sobre o respectivo programa. Ambos foram arquivados. O Projeto

(1993-1996), membro da Comissão Técnica de Assessoramento à Coordenação Nacional de Saúde Bucal do Ministério da Saúde (2004-2015).

69 Eduardo Jorge Martins Alves Sobrinho nasceu em 26 de outubro de 1949, em Salvador (BA), é médico. Era filiado ao PT, hoje faz parte do Partido Verde (PV). 
de Lei $\mathrm{n}^{\circ} 1.133 / 1991$, de autoria da deputada Regina Gordilho ${ }^{70}$ do Partido Democrático Trabalhista (PDT), do Rio de Janeiro foi apresentado em 18 de junho de 1991 e tinha como objetivo tornar obrigatória a fluoretação do cloreto de sódio pelas indústrias produtoras em todo o território nacional. (BRASIL, 1991b) Apesar de ter obtido parecer favorável pelo relator, o deputado Maurílio Ferreira Lima, ${ }^{71} \mathrm{o}$ projeto de lei não foi apreciado na Comissão de Justiça, tendo sido arquivado. Em 1 de junho de 1992, foi submetido o PL n².852/1992, pelo deputado José Maria Eymael, ${ }^{72}$ do Partido Democrata Cristão (PDC) de São Paulo, que buscava estabelecer a obrigatoriedade de fluoretação da água distribuída para consumo humano. (BRASIL, 1992a) O Projeto recebeu parecer contrário do deputado Antonio Faleiros, ${ }^{73}$ do Partido do Movimento Democrático Brasileiro (PMDB) de Minas Gerais, devido à existência de Lei anterior, a de $n^{\circ}$ 6.050, de 24 de maio de 1974, e outras portarias do Ministério da Saúde que regulamentam e aprovam normas e padrões sobre a fluoretação da água dos sistemas públicos e, assim, o objeto já estaria sendo atingido por instrumentos legais vigentes.

No ano de 1993, uma Identificação de Proposição (INC) 344/1993 é feita pelo deputado Pedro Correa ${ }^{74}$ do Partido da Frente Liberal (PFL) de Pernambuco sugerindo ao poder executivo, através do Ministro da Saúde, que se processe a fluoretação do sal refinado ou moído e que as indústrias beneficiadas do sal deverão adquirir o equipamento e o fluoreto de sódio necessários. Os deputados e senadores dos partidos PDT e PFL se posicionaram como favoráveis à fluoretação do sal. O PFL integrava a base aliada do PRN. Já aqueles do PT, PDC e PMDB, partidos de oposição ao governo, adotaram ponto de vista contrário.

Tratando sobre as experiências exitosas em outros países, a publicação da OPAS citou que a viabilidade do programa na Jamaica foi atribuída à existência de um único produtor, sendo que o programa implantado atingiu grande sucesso na redução da cárie dentária. (PAHO, 2005) Este fato é distinto do que ocorria no Brasil, tendo em vista que existiam muitos produtores de sal de diferentes portes, o

70 Regina Helena Costa Gordilho, empresária, nasceu em 12 de maio de 1933 em Salvador.

71 Maurílio Figueira de Ferreira Lima nasceu em 29 de março de 1940, em Limoeiro (PE). É advogado, filiado ao PMDB.

72 José Maria Eymael nasceu, em 1939, na cidade de Porto Alegre (RS). É graduado em Filosofia e Direito, era filiado ao PDC e, em 1995, fundou o Partido Social Democrata Cristão (PSDC).

73 Antonio Faleiros Filho nasceu em 12 de janeiro de 1948, em Estrela do Sul. É médico, especializado em obstetrícia e medicina do trabalho. Era deputado federal pelo PMDB de Goiás.

74 Pedro da Silva Correa de Oliveira Andrade Neto, médico, nasceu em 7 de janeiro de 1948, no Rio de Janeiro (RJ). No momento da indicação, era filiado ao PFL. Antes do PFL foi da Arena e atualmente é filiado ao Partido Popular (PP). 
que ocasionava diferentes tipos de produtos, sendo que o método da fluoretação do sal exigia um controle rígido para o sucesso da técnica. Ademais, os consultores do Ministério da Saúde à época temiam um aumento do custo do sal de cozinha para a população, tendo em vista que não existia produção nacional do insumo para o modo de uso citado, causando a necessidade de importação da Alemanha e isto faria com que um produto que era de amplo acesso e uso da população, pudesse deixar de sê-lo devido aos altos custos do material.

Foi uma comissão visitar as salineiras no Rio Grande do Norte. Uma coisa é fluoretar o sal do Uruguai que não produz sal, importar todo seu sal, e portanto tem o controle na fonte. Outra coisa é chegar no Rio Grande do Norte e dar conta que tinha trezentos produtores de sal, com as mais variadas e diferentes formas tecnológicas, uns mais sofisticados e outros menos. A gente percebeu que poderia haver um risco de monopolização na produção do sal, matando os 'pequeninhos' que não teriam a menor condição de fluoretar. A fluoretação do sal requer uma produção de baixa concentração de umidade e aquelas salineiras não tinha a menor chance, o sal vem úmido, e o sal úmido o que acontece? o flúor fica na fase líquida que acaba se concentrando e não se distribuindo uniformemente no sal. Então, tem que ter um processo de produção que faça com que essa concentração fique distribuída adequadamente no sal. A gente criou informes técnicos de incapacidade de produção e de segurança da fluoretação do sal no Brasil. Isso por um lado, pelo outro lado a ideia de que o sal refinado eventualmente fluoretado no Brasil seria tão caro que seria inacessível a quem também era inacessível a água. (Entrevistado 9, dentista, consultor, professor universitário)

As salineiras que pleiteavam o comércio do produto foram alvo de inspeção e testes por comissão da DNSB do Ministério da Saúde. A comissão concluiu que as empresas não dispunham do controle necessário para a distribuição homogênea do flúor no sal e o alcance das especificações mínimas de qualidade. De forma contrária à adição de iodo no sal de cozinha, as diferentes concentrações de flúor encontradas nas amostras testadas poderiam ocasionar sérios riscos de fluorose à população brasileira.

Segundo o Entrevistado 9, o assédio que os consultores sofreram em visitas às salineiras para testar os produtos revela os interesses econômicos em jogo. Alguns empresários de grandes salineiras fizeram propostas consideradas pelos entrevistados como indecorosas aos técnicos do Ministério da Saúde tentando pactuar padrões de qualidade inalcançáveis aos pequenos produtores e assim assegurar seu monopólio, o que implicava uma forma de corrupção. A moeda de barganha era 
que as empresas custeariam a produção do sal e o Ministério da Saúde não necessitaria subsidiar o produto.

$\mathrm{Na}$ visita técnica para avaliação, realizada por consultores do Ministério da Saúde em Cabo Frio, ficou evidente que a empresa possuía privilégio de informações e já dispunha do produto pronto para venda. O intuito era ser a empresa pioneira na venda do sal fluoretado no Brasil. Outro entrevistado suspeitou de esquema de corrupção que perpassava o processo de fluoretação do sal de cozinha.

No nível nacional, a FIO, através de seu presidente Swendenberg Barbosa, solicitou ao Ministro da Saúde, em audiência concedida em 28 de abril de 1992, a adoção de uma política baseada nas resoluções da I CNSB e nos Enatespo, assim como a obrigatoriedade das ações de Odontologia no SUS, com dotação orçamentária específica. Solicitou, também, apoio para a realização da II CNSB e a ampliação da infraestrutura e recursos humanos para a DNSB, apesar de terem se abstido da indicação de um nome para ocupar a coordenação. (FIO..., 1992b)

O documento final do VIII Enatespo, realizado em São Paulo (SP), de 21 a 25 de outubro, destacava que os programas de fluoretação do sal de cozinha não deveriam ser implementados, mesmo que, em algumas reuniões, sem ampla discussão com a sociedade civil e as instâncias políticas como o Congresso Nacional, reafirmando a luta pelo provimento das águas de abastecimento público de "boa qualidade, clorada e fluoretada para todos os brasileiros”. (ENATESPO, 1991) Outro ponto de destaque foi a inadequação da prática odontológica ainda vigente no país, centrada em ações clínico-cirúrgicas individuais e em enfoques biologicistas "em detrimento da compreensão e enfrentamento dos determinantes sociais do processo saúde-doença”. (ENATESPO, 1991) A tomada de posição do Enatespo era consonante com o Movimento da Reforma Sanitária Brasileira.

O documento, publicizado através de número especial da revista Saúde em Debate relacionado ao VIII Enatespo, apresenta textos nos quais se pode apreender as tomadas de posição do grupo. Foi recomendado que o projeto municipal de saúde contivesse estudo aproximado da realidade, contemplando os determinantes sociais, a identificação de problemas de saúde bucal a partir da epidemiologia, modelo assistencial baseado na integralidade das ações de SB com ênfase nas ações básicas, método preventivo-educativo, utilização de pessoal auxiliar, sistemas de trabalho de cobertura ampla, a criação de centros de referência para atenção de níveis secundário e terciário, sistemas de referência e contra referência, instrumentos adequados para avaliar o impacto das ações desenvolvidas e definição clara dos recursos financeiros. Destacou-se, também, os recursos humanos e o controle social. (SOUZA, 1991) 
Ademais, a plenária apontou a ausência de um documento oficial que traduzisse a PNSB do governo Collor e ainda que tenha reconhecido que a coordenação de saúde bucal do Ministério da Saúde tivesse incorporado algumas propostas oriundas dos Enatespo e de outras instâncias democráticas, isto não era suficiente para assegurar a implantação e a continuidade das ações pois apenas o processo democrático de elaboração poderia legitimar e assegurar a continuidade da proposta da política nos níveis nacional, estadual e municipal. (ENATESPO, 1991) O documento também reivindicava a convocação da II CNSB e reiterava a defesa pela democracia e seu desenvolvimento no país.

Os consultores do Ministério da Saúde concluíram pela inviabilidade da fluoretação do sal, no Brasil, em condições seguras e recomendaram a descontinuidade do Programa. Ademais, era inconstitucional a existência de duas leis sobre fluoretação em território nacional. Assim, foi demandado parecer da Procuradoria Jurídica, tendo sido atestado o exposto. O ministro Alceni Guerra foi exonerado e em seu lugar foi nomeado o ministro Adib Jatene que, ao receber o citado parecer da Procuradoria Jurídica, decidiu pela extinção do Programa.

Não era possível fazer responsavelmente. Se pudesse fazer para a região Norte com certeza teria sido feito, porque a região norte nunca teve sistema de água fluoretada [...] houve esse interesse para estudar a possibilidade do sal com flúor, mas de novo era método coletivo e o estudo era para ver a possibilidade de em áreas que não tem, especialmente a região Norte e alguma parte do Nordeste era introduzir sal com flúor mas operacionalmente não era possível. Eram 400 empresas salineiras como é que ia controlar? Qual a dose que você ia usar? Se vocêfosse usar no Rio Grande do Sul, os gaúchos comem muito sal, você tinha que baixar a quantidade de flúor, se fosse usar no Norte, o uso é menor, você tinh a que aumentar a concentração de flúor, então tinha uma dosagem mas isso era verdadeiro em uma determinada localidade. (Entrevistado 14, dentista, professor universitário)

Assim, a Portaria ${ }^{\circ}$ 851, de 4 de agosto de 1992, publicada em 7 de agosto, cita o parecer da Consultoria Jurídica no sentido da edição da Lei Federal existente para imposição da obrigatoriedade da fluoretação do sal destinado ao consumo humano resolveu cancelar a Portaria que regulamentava o Programa Nacional de Controle da Cárie pelo método de fluoretação do sal. (BRASIL, 1992e) Após, os registros dos produtos alimentícios Biosal e MOC da empresa Cia. Salinas Perynas foi cancelado, através da Portaria n 43, de 4 de maio de 1993.

Apesar do cancelamento do Programa, o prefeito de Cabo Frio, Ivo Saldanha, divulgou a manutenção do Decreto Municipal assim como a continuidade da pro- 
dução e comercialização do sal fluoretado. A Associação dos Salineiros impetrou um Mandato de Segurança a fim de invalidar o Decreto Municipal. O prefeito justificou a ação devido ao país ser um campeão mundial em cáries. (GUEDES, 1992)

A ABO, através do seu presidente Pedro Martinelli, enviou carta ao Ministro criticando a extinção do Programa, a ausência de um diretor na Coordenação Nacional de Saúde Bucal e o distanciamento do setor das entidades de classe odontológicas. (ABO, 1992) Ademais, afirmou existir um temor de "[...] não estarmos tomando as decisões mais corretas na defesa da saúde de nossa comunidade”. (ABO, 1992, p. 13)

Houve uma mobilização político-partidária crítica à decisão de Adib Jatene e buscando retroagir a decisão por meio de manifestos e de novas iniciativas legislativas. O deputado federal Flávio Palmier da Veiga, do Partido da Reconstrução Nacional (PRN) do Rio de Janeiro, ${ }^{75}$ através de um abaixo assinado, "em nome da classe odontológica e em benefício do povo brasileiro", solicitava o cancelamento da Portaria MS/GM no 43/1993 que retirou o registro dos produtos Biosal e MOC. (VEIGA, 1993) O deputado também criticou o coordenador nacional de Saúde Bucal, em exercício, dr. Mércio de Azevedo Ferreira, por ter afirmado em entrevista ao jornal $O$ Globo que metade da população brasileira era beneficiária de água fluoretada em sua residência. (VEIGA, 1993)

No âmbito do Congresso Nacional, dois projetos de lei e um requerimento de informações com o tema da fluoretação, no período citado, foram elaborados por senadores. Os três atos legislativos foram da autoria do senador Júlio Campos, ${ }^{76}$ do Partido da Frente Liberal (PFL).

Em 30 de junho de 1993, foi aberto o requerimento no 656/1993 solicitando informações ao Ministro da Saúde relacionadas à suspensão da fluoretação do sal no Brasil. No ano seguinte, em 23 de março de 1994, o mesmo senador elabora o Projeto de Lei $n^{\circ} 19 / 1994$ que dispunha sobre a obrigatoriedade da fluoretação do sal que, entretanto, foi arquivado no ano seguinte. Em 1997, há nova tentativa, através do PL n $58 / 1997$ com objeto semelhante que também é arquivado em 1999.

A decisão do ministro Adib Jatene pela suspensão do projeto foi apoiada por vários sanitaristas que participaram de projetos e movimentos a favor da fluore-

75 Flávio Palmier da Veiga nasceu em 2 de fevereiro de 1932. Era advogado e professor universitário, foi vereador, deputado estadual do Rio de Janeiro, por seis mandatos, e deputado federal, por três mandatos.

76 Júlio José de Campos nasceu em 11 de dezembro de 1946, em Várzea Grande. É engenheiro e empresário. No período, foi senador pelo estado de Mato Grosso pelo Partido da Frente Liberal (PFL). 
tação das águas de abastecimento público desde a década de 1950, além dos integrantes que haviam participado do MBRO e dos Enatespo assim como pela Aboprev.

A Rede Cedros seguiu publicando em seus jornais experiências exitosas de fluoretação do sal na Costa Rica, México, França, mas, também, estudos sobre o flúor na água. Entretanto, além da polarização em torno dos grupos que eram contra ou a favor da fluoretação do sal, existiam cirurgiões dentistas do movimento anti-flúor sistêmico que também eram contrários à fluoretação da água.

Manifesto na internet intitulado “Flúor na água não” aponta que o site Fluoride Action Network iniciou um movimento pedindo o fim da fluoretação das águas e já contava com mais de 1000 pessoas até 2007, sendo seis destes profissionais: Nelson Luiz Busatta, de Tapurah, dentista; Alexandre Cruz, do Rio de Janeiro, hidrogeólogo; Luciano Fonseca, de Juiz de Fora, médico; Jorge Jamili, do Rio de Janeiro, médico; Olympio Faissol Pinto, do Rio de Janeiro, dentista; e Paula Yamaguti, de São Paulo, dentista.

As causas explicitadas para o pleito afirmam que o fluoreto não é um nutriente essencial, que nenhuma doença jamais foi ligada à deficiência de fluoreto, que o benefício do flúor é principalmente tópico e não sistêmico e que o flúor seria um veneno cumulativo e, portanto, já que o flúor é desnecessário, não haveria razão para forçar as pessoas a beber o flúor em seu suprimento na água. (CRUZ, 2007)

Olympio Faissol Pinto, ${ }^{77}$ dentista de muitos políticos, como Fernando Collor e Brizola, além de outros artistas, deu uma entrevista no Programa Jô Soares, da Rede Globo, argumentando os motivos contra o flúor sistêmico e criticando a fluoretação das águas no Brasil, em maio de 1990. Aproximadamente dez dias depois, o Ministério da Saúde enviou o consultor Jaime Cury ${ }^{78}$ que explicou os motivos e a ação do flúor defendidos pela Coordenação Nacional de Saúde Bucal.

Motivo de destaque não apenas na mídia televisiva, o tema controverso do flúor também ganhou página inteira de discussão sobre toxicidade, possíveis malefícios assim como o posicionamento da Aboprev a favor da fluoretação. A matéria ilustra as distintas tomadas de posição coexistentes no espaço. De um lado, os críticos do flúor sistêmico na água e, do outro, seus defensores representados na

77 Olympio Faissol Pinto formou-se em Odontologia pela UFRJ, em 1957, e possui mestrado em Odontologia pela Georgetown University (1960). É membro Fundador da Sociedade Brasileira de Reabilitação Oral, cirurgião dentista da Clínica Odontológica Olympio Faissol Pinto.

78 Entrevista concedida por Jaime Cury no Programa Jô Soares na rede Globo em maio de 1990. 
matéria por Yvonne Buischi, presidente da Aboprev no período. (FOLHA DE SÃO PAULO, 1990)

Os dentistas associados à Aboprev realizaram eventos científicos contrapondo diferentes opiniões sobre o flúor. Foram realizados dois eventos denominados SIM Flúor, um em Porto Alegre e outro no Rio de Janeiro, trazendo os argumentos científicos nos quais se baseava a defesa do flúor na água.

Era assim absolutamente anti-flúor, ele chamou todos aqueles fundamentalistas contrários ao flúor, os que tem nos Estados Unidos e na época e nós fizemos os Sim flúor. Era o simpósio com relação ao flúor, e nesse simpósio chamamos, confrontamos pessoas a favor e contra o flúor, não era para fazer um simpósio a favor do flúor, era para as pessoas verem o anti-flúor e o a favor do flúor. Tinha um que trouxe um filminho de uma vaca se quebrando toda porfluorose bovina e ele mostrava isso com uma planta de alumínio no fundo soltando fumaça dizendo: - 'Olha essa vaca está se esfacelando porque os ossos tem muito flúor' e aí ele terminava assim: 'É isso que vocês querem pros filhos de vocês?' [...] então saiu na imprensa que todo mundo ia morrer com afluorose, que afluorose deixava os ossos fracos e a mesmo tempo a gente tinha uma contraposição acadêmica. Veio gente dos Estados Unidos, veio gente da Noruega, da Inglaterra, verdadeiros acadêmicos, não aqueles fundamentalistase ganhou a questão acadêmica definitivamente [...]. (Entrevistado 9, dentista, consultor, professor universitário)

Faissol também presidiu evento científico, o congresso Eco Odonto Rio 92, com muitos pesquisadores de outros países, enfocando diversos temas e, dentre eles, a toxicidade do amálgama e os problemas relacionados ao flúor sistêmico. Em entrevista ao Jornal do Rio, da Rede Bandeirantes, Faissol ${ }^{79}$ enfatizou:

O Brasil tem 66 escolas de Odontologia e 11 mil dentistas, eu acho que chegamos num ponto em que o povo vai deixar de acreditar na Odontologia se nós não fizermos alguma coisa. Nós temos aí mais de 40 anos de campanha de prevenção colocando flúor na água e não melhorou nada, que negócio é esse? Então um erro de 40 anos deverá prosseguir?

O dentista também explicou, em entrevista ao Programa Bom Dia Rio, da Rede Globo fluminense, em 1992, que sua defesa anti-flúor se iniciou na década

79 Entrevista concedida por Olympio Faissol Pinto a Frederico Roriz do Jornal do Rio da rede Bandeirande de Televisão na ocasião do evento Eco Odonto Rio 92. Rio de Janeiro, Rede Bandeirantes, 1992. 
de 1960, em um estudo seu, nos Estados Unidos, que teve ampla aceitação pelos profissionais renomados americanos.

Em outros programas de televisão, Faissol levou pesquisadores americanos que reforçavam seus argumentos. O tema também ganhou destaque em jornais de veiculação em todo Brasil, como o Jornal Nacional, da Rede Globo, que veiculou a ocorrência do Congresso Eco Odonto 92 com a tese anti-flúor, mas, também, as respostas do Ministério da Saúde e da Aboprev.

O presidente Fernando Collor de Mello sofreu impeachment em 29 de dezembro de 1992 e Itamar Franco assumiu a presidência da República. Nos anos subsequentes, as discussões polêmicas sobre a fluoretação do sal de cozinha e das águas de abastecimento público permaneceram em pauta.

O Jornal da Aboprev descreveu um simpósio realizado em 1993 com a participação do Hélio Uchoa, da FOUERJ e Rede Cedros, Roberto Vianna, da Rede Cedros, e Jaime Cury, da Aboprev (ABO..., 1993) para contrapor os pontos de vista sobre o flúor em defesa da fluoretação das águas. A Rede Cedros publicou dados da fluoretação do sal em seus boletins, quanto à experiência no México (BOLETIM INFORMATIVO, 1993), Costa Rica (BOLETIM INFORMATIVO, 1994) e França. (BOLETIM INFORMATIVO, 1995)

Após passar por nova reestruturação interna, o Ministério da Saúde passou a denominar a antiga DNSB como Coordenação de Saúde Bucal. José Carlos Cativo Gedeão, do campo burocrático, é nomeado coordenador de Saúde Bucal, em 24 de maio de 1993. Em 14 de julho de 1993, o ministro da Saúde Jamil Haddad designa comissão para planejar a II CNSB. Os membros efetivos da comissão foram: Swendenberg Barbosa, pelo Conselho Nacional de Saúde, coordenador geral da II CNSB; José Carlos Cativo Gedeão, pelo Ministério da Saúde; Hosana Garcez Moreira e Edila Sinedino Maioranna, pelas entidades associativas odontológicas; Olga Barbosa Laranjeiras, pelo Conselho Nacional de Secretários de Saúde (Conass); Déa Costa Ramos, pelo Conselho Nacional de Secretarias Municipais de Saúde (Conasems); Osdyr Brasileiro Matos, pelo governo do Distrito Federal; Maria do Amparo Vieira de Souza e Elson Nildes Soares, como representante dos usuários.

A II CNSB ocorreu de 25 a 27 de setembro de 1993 e aprovou diretrizes e estratégias políticas para a saúde bucal no país, considerando-a como um direito, um novo modelo de atenção à saúde bucal, recursos humanos, financiamento e controle social.

No período de 1993 a 1995, foram desenvolvidas poucas ações na coordenação de saúde bucal. João Antônio Caminha, professor da UFRGS, prestou consultoria neste período. O coordenador não fez nenhuma intervenção significante, com 
exceção do desenvolvimento de uma ficha de registro odontológico que permitia o registro de procedimentos individuais e ações coletivas como palestras, ensino de escovação, dentre outras.

Quanto ao planejamento orçamentário das ações de saúde bucal no período de 1990 a 1994, que expressam o grau de priorização das ações ao interior do governo, observa-se maior montante gasto em 1990, quando ainda existiam ações de assistência previdenciárias de saúde bucal (Tabela 3). Nos anos subsequentes, o percentual destinado às ações de saúde bucal foi bastante reduzido, principalmente após a saída de Sergio Weyne do cargo de diretor da DNSB. O orçamento de 1994 representou 0,04\% do planejado para o Ministério da Saúde, sendo menor que aquele de 1989, quando a DNSB estava no início da implementação de suas ações quando representava 0,10\%. Destaca-se, também, que a proporção dos valores destinados à saúde bucal neste período superou bastante aquele investido na segunda metade da década de 1980 (Tabela 3).

Em 1995, assumiu a dentista e especialista em saúde pública, Sônia Maria Dantas de Souza, de Belém (PA), que foi responsável pela implementação da política de inserção da Saúde Bucal no PSF, no ano 2000, objeto do próximo capítulo deste trabalho.

No período compreendido entre 1990 e 1994, em síntese, a PNSB priorizou o controle da cárie. O espaço da PNSB ficou polarizado pelo debate entre sanitaristas ou profissionais vinculados ao campo burocrático, que defendiam a fluoretação da água, e o polo do mercado, que propugnava a introdução da fluoretação do sal (Quadro 10). 


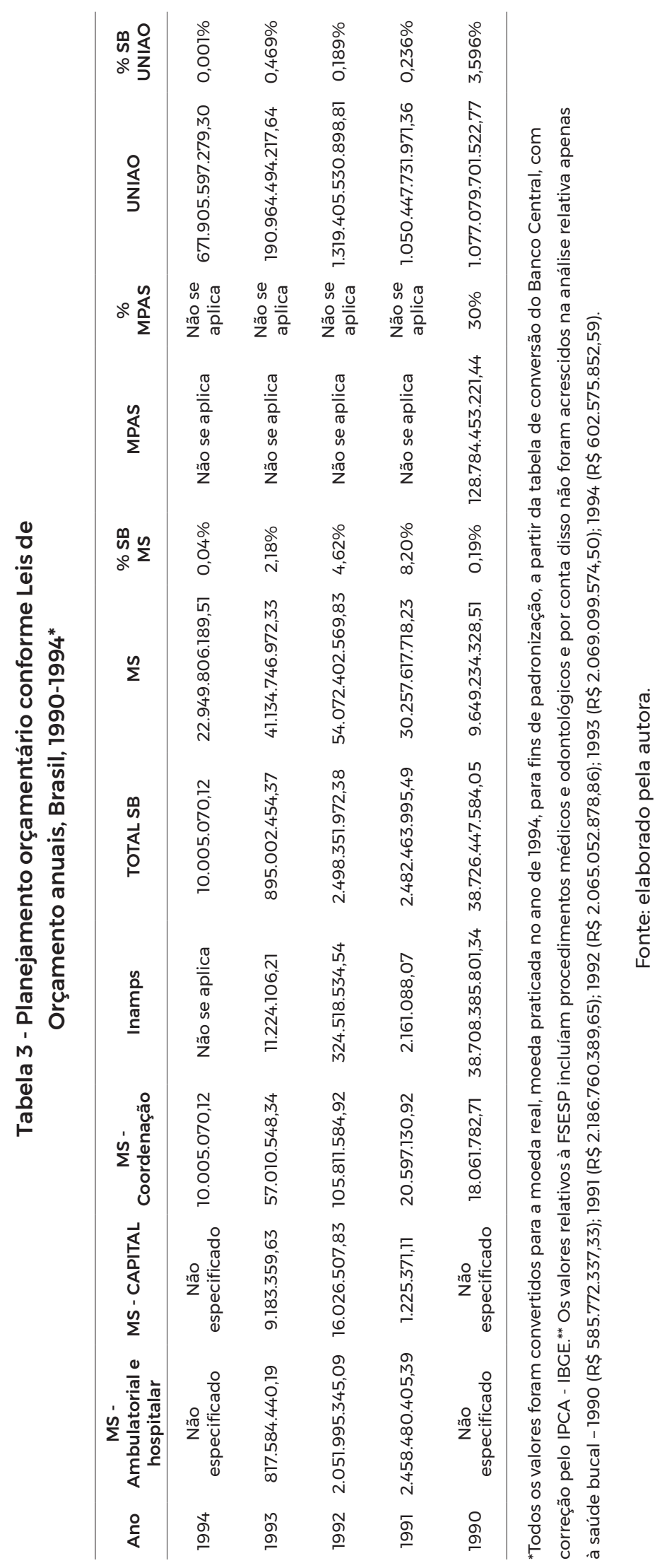

Produção Social da Políticas de Saúde Bucal no Brasil / 141 


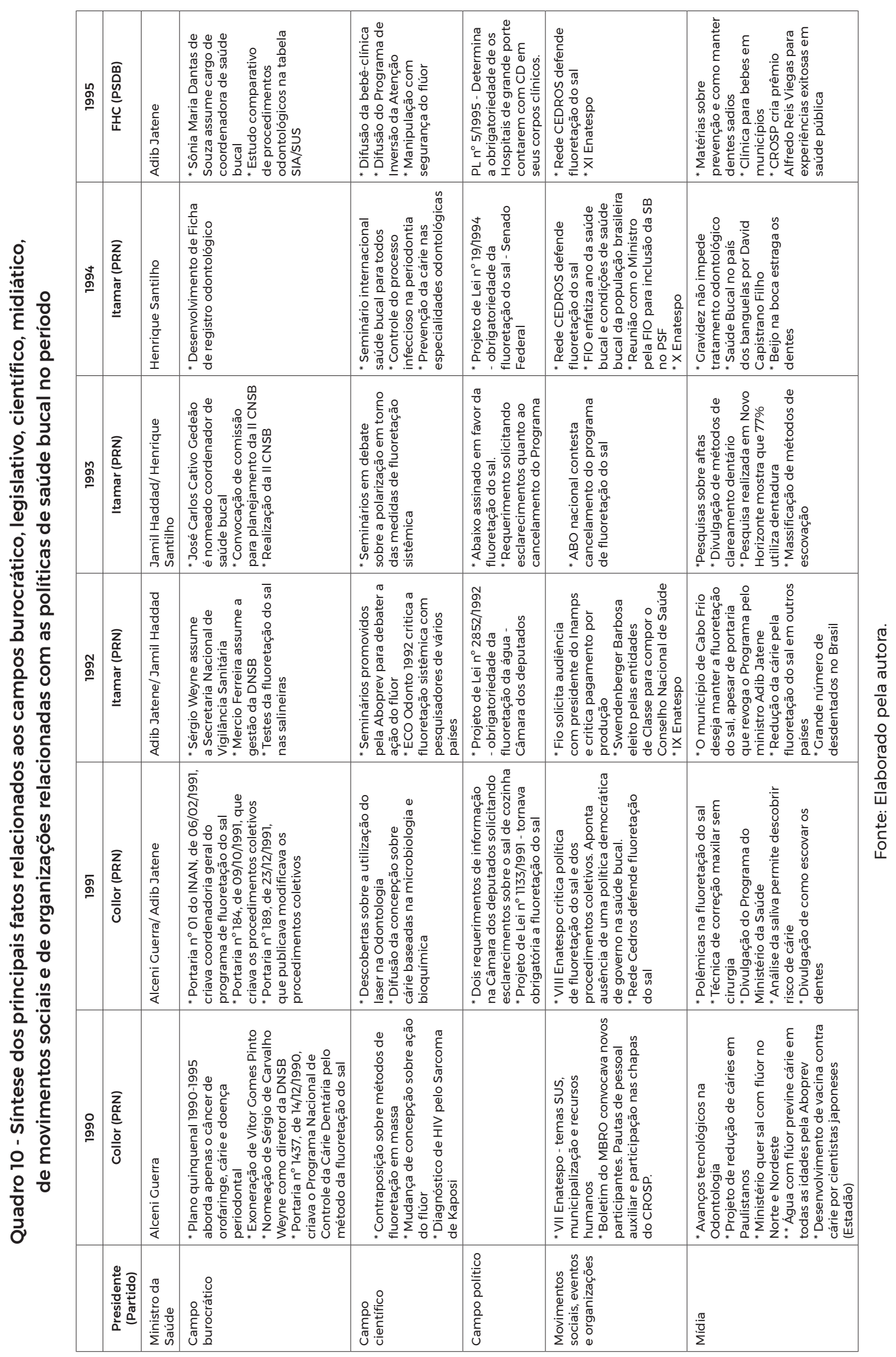

142 / Thais Regis Aranha Rossi 


\section{Grupos e agentes que influenciaram o espaço de formulação da política}

Após um resgate historiográfico das principais respostas do Estado quanto aos problemas bucais da população brasileira, no período de 1990 a 1993, duas políticas foram destacadas, a mudança de procedimentos na tabela SIA-SUS com os procedimentos coletivos e a tentativa de fluoretação do sal de cozinha.

Nas duas políticas, observa-se a forte influência que a Aboprev exerceu, seja através de congressos e publicações no campo científico seja através da presença de seus membros na gestão ou em comissões de assessoramento à DNSB do Ministério da Saúde.

O Quadro 11 mostra uma faixa etária de 54 a 90 anos dentre os entrevistados que influenciaram o espaço de formulação das políticas no período citado. A quase totalidade pertencia ao sexo masculino e todos eram graduados em Odontologia. Observou-se diferenças geracionais relacionadas às tomadas de posição. Os agentes mais velhos defendiam a fluoretação do sal, como Mário Chaves e Hélio Wanderley Uchoa, ambos da Rede Cedros. Dentre aqueles de geração intermediária, estavam Pedro Martinelli, presidente da ABO, nascido em 1943, que apoiava a fluoretação do sal, os membros da Aboprev e consultores do MS. Os mais jovens integravam o MBRO que, a partir do início da década de 1990, deixa de ser tão atuante como na década de 1980 e as críticas passam a ser exercidas nos Enatespo (Quadro 11).

Dentre as ocupações dos entrevistados no momento da entrevista, muitos pertenciam ao campo científico ou se encontravam, simultaneamente, nos campos científico e burocrático. Outros entrevistados faziam parte apenas do campo burocrático, exercendo ou participando da gestão, no nível estadual ou municipal. Devido ao tempo decorrido superior a 20 anos do período de estudo ao momento da entrevista, muitos já se encontravam aposentados. Entretanto, aqueles com faixa etária menor ainda se encontravam em plena atividade de docência, em cargos burocráticos ou políticos. Alguns ainda permaneciam acompanhando e integrando movimentos de crítica às políticas nacionais de saúde bucal no país.

A inserção dos dentistas que ocupavam o espaço de formulação e crítica das políticas era predominantemente burocrática. Dentre os consultores, existiam aqueles que se inseriam no campo científico com grande acumulação de capital científico. O cargo máximo na Coordenação de Saúde Bucal, inicialmente chamada de DNSB, era ocupado por agente com inserção predominante no campo científico, com capital simbólico acumulado e que, devido ao capital social decorrente de ligações com familiares do recém-eleito presidente, foi indicado para o cargo. 
O chefe da Divisão apresentava alto capital burocrático e baixo capital científico, mesmo com inserção neste campo (Figura 11).

Os profissionais que participaram do grupo técnico cientifico da DNSB apresentaram capital científico alto ou muito alto, dentre aqueles pertencentes à Aboprev. Quanto ao capital político, aqueles com maior acumulação eram vinculados ao subespaço de crítica, geralmente vinculados a partidos de esquerda. Dentre os consultores, um deles era filiado ao PMDB. A maioria dos consultores e o coordenador de saúde bucal não apresentavam filiação partidária (Quadro 11).

Como a maioria dos entrevistados apresentava relação com a DNSB/Coordenação ou exercia cargos burocráticos em outras esferas, também se percebe acumulação mediana de capital burocrático. Dentre os consultores, acrescentou-se Sylvio Palermo Gevaerd, representado pela letra A3, ${ }^{80}$ que não foi entrevistado, mas exerceu papel importante no espaço de formulação das políticas. O grupo de consultores pertencente à Aboprev apresentou capital científico alto ou muito alto.

O polo dominante no espaço de formulação das políticas de saúde bucal era formado pelo Diretor da DNSB e seus consultores também ligados à Aboprev. Estes apresentavam maior volume global de capital (Quadro 12).

Já os grupos de contestação e crítica das políticas como o MBRO, no início da década, mais especificamente através dos Enatespo, entre 1990 e 1993, apresentavam capital político médio, alto e capital burocrático médio. A aproximação neste grupo se deu através das disposições políticas, como participação em partidos políticos, em movimentos estudantis e em movimentos pela democracia.

Os entrevistados que se posicionaram a favor da fluoretação do sal, assim como outros dentistas, como Mário Chaves $(\mathrm{A} 1)^{1}$ e Paulo Freire (A2), ${ }^{1}$ possuíam capital burocrático médio ou muito alto e capital político médio. Os dentistas que participavam da Rede Cedros, favoráveis à fluoretação do sal, ocupavam posições variadas no espaço, apresentando capitais distintos. Quando se analisa os agentes da Aboprev, que foram inicialmente favoráveis, conforme registrado em publicações da Associação, mas depois se declararam contrários à fluoretação do sal de cozinha devido a análises por membros que também eram consultores do MS, segundo seus capitais burocrático e científico, observa-se alto capital científico e burocrático mediano.

80 Sylvio Palermo Gevaerd, Mário de Magalhães Chaves e Paulo Freire são falecidos e não par ticiparam do estudo através de entrevistas, entretanto, suas trajetórias foram analisadas por meio de biografias disponibilizadas, informações em outras entrevistas, material publicado e currículo Lattes, no caso de Sylvio Palermo Gevaerd. Para mapear as tomadas de posição, foram analisadas publicações assim como as entrevistas concedidas por pares descritos na metodologia. 


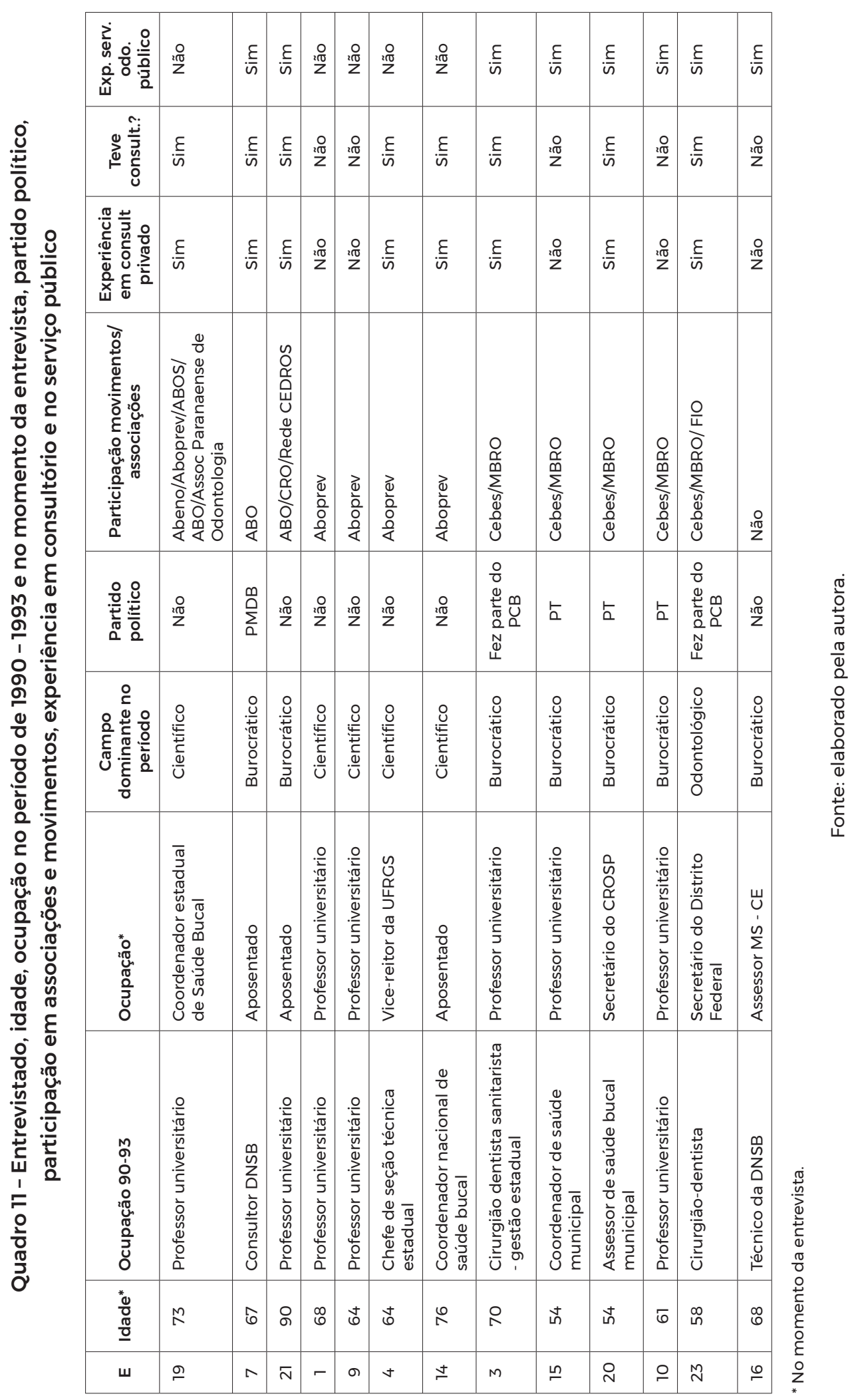




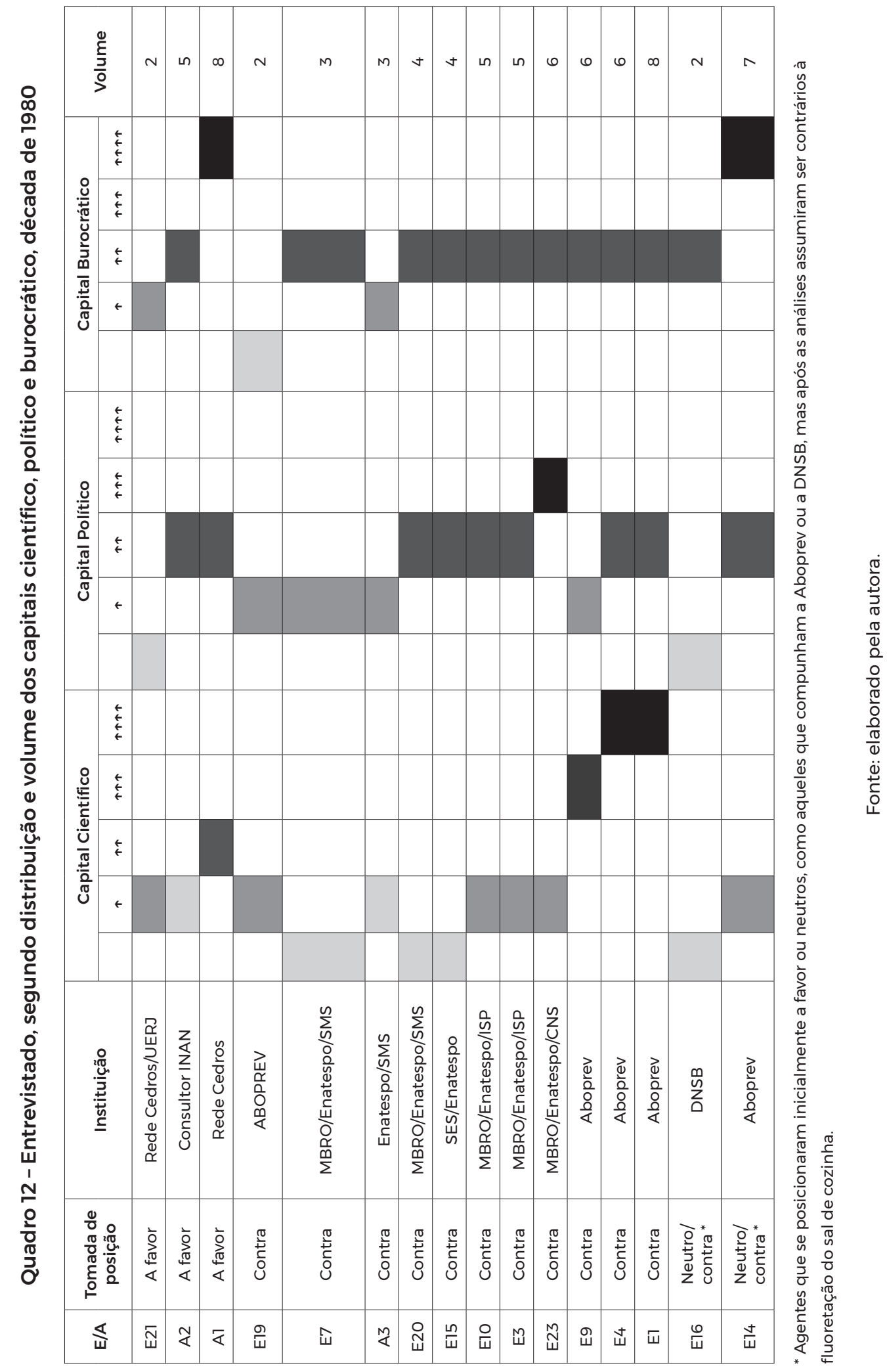


Figura 11 - Agentes participantes do espaço de formulação de crítica das políticas de saúde bucal segundo capitais burocrático e científico, 1990-1993

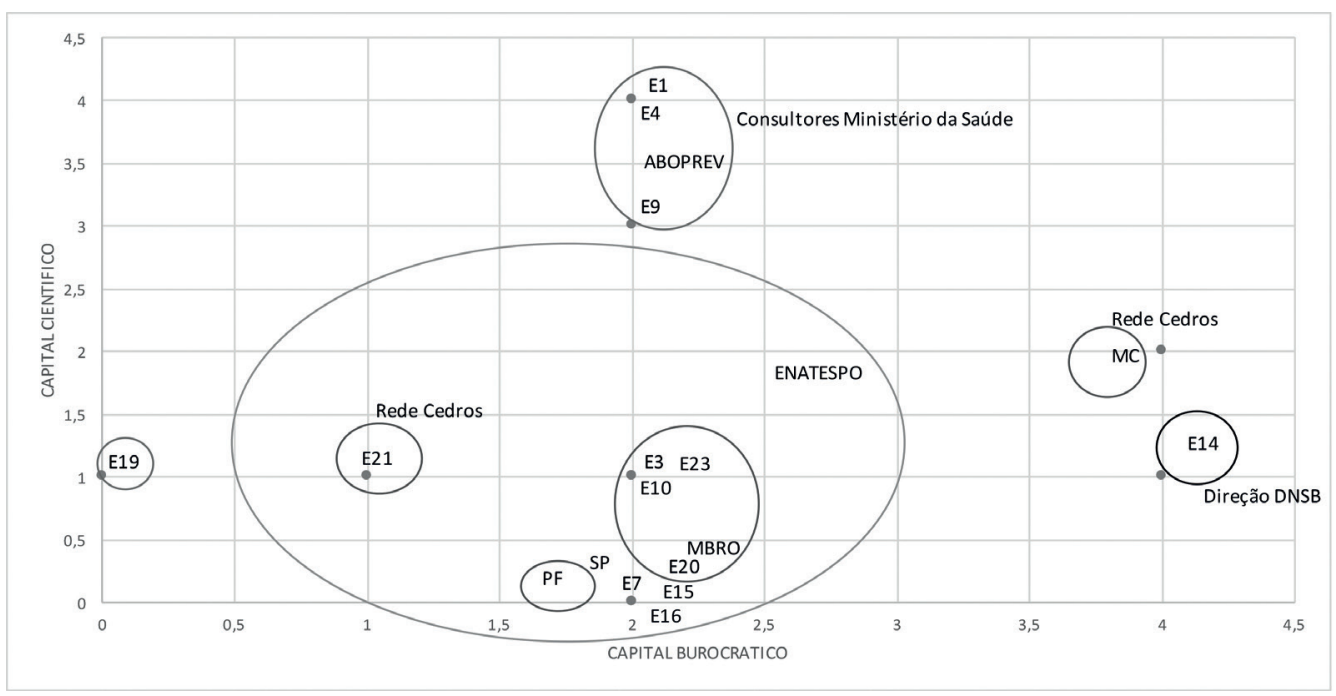

Fonte: Elaborado pela autora.

Figura 12 - Agentes participantes do espaço de formulação de crítica das políticas de saúde bucal, segundo capitais burocrático e político, 1990-1993

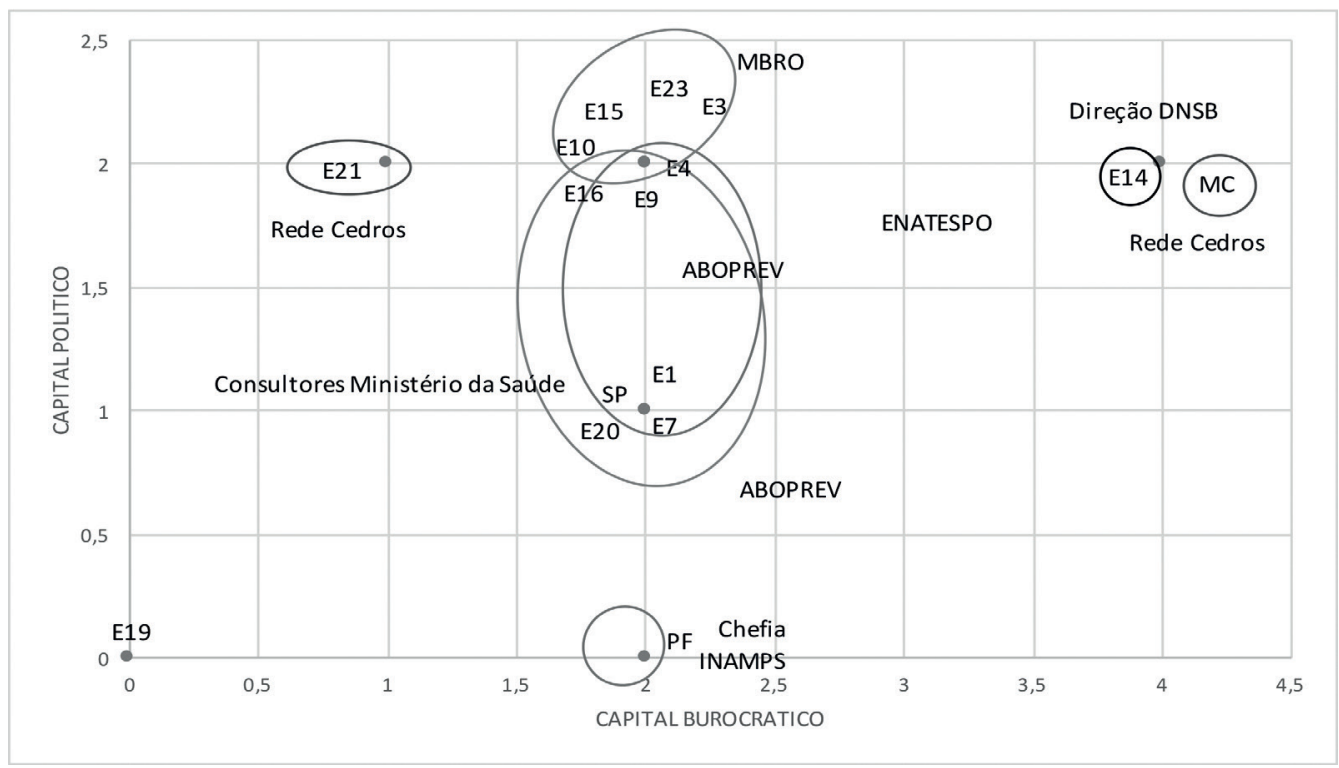

Fonte: elaborado pela autora. 
Figura 13 - Agentes participantes do espaço de formulação de crítica das políticas de saúde bucal, segundo capitais científico e político, 1990-1993

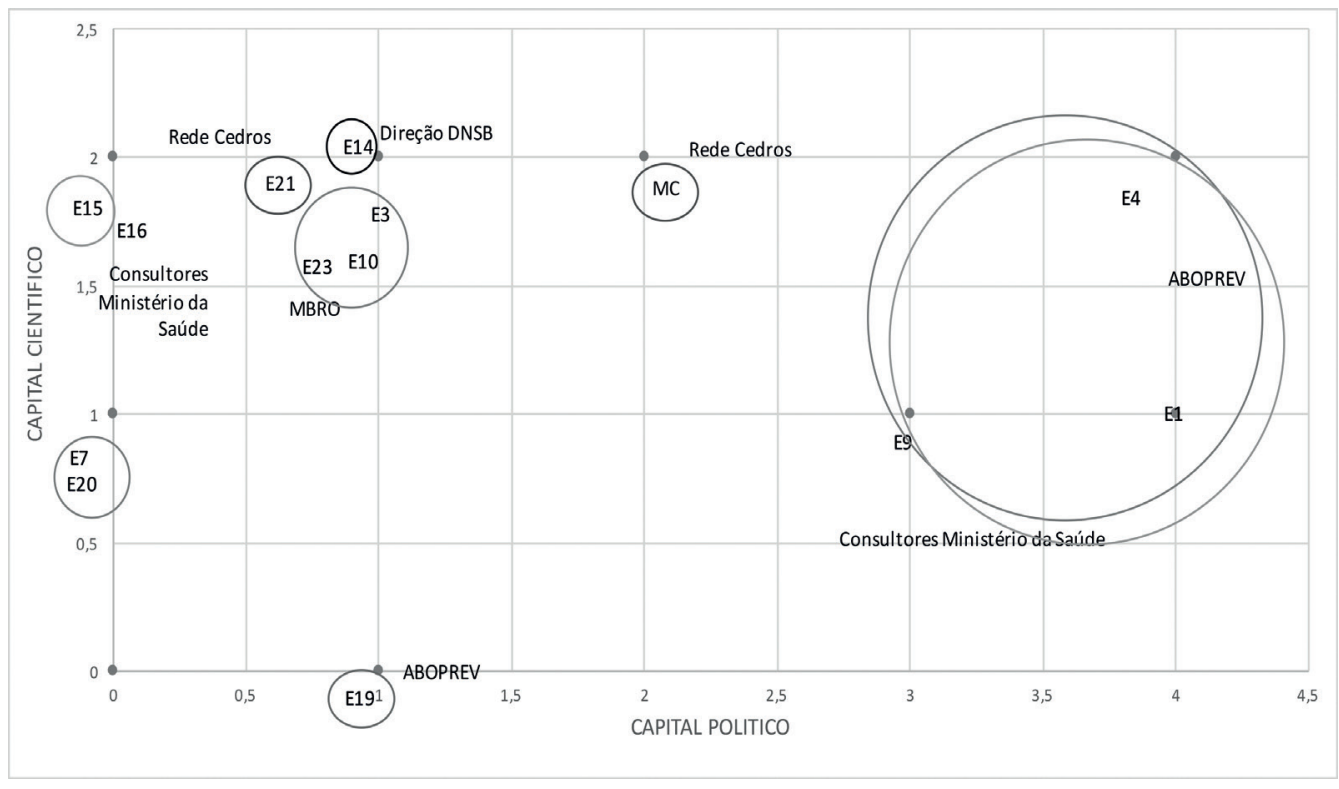

Fonte: elaborado pela autora.

Observou-se, também, diversidade na acumulação desses capitais dentre aqueles que participavam de movimentos contra hegemônicos, como o MBRO e os Enatespo, declaradamente contrários à política (Figura 11). O espaço de relações se modifica quando se analisa os capitais burocrático e político. Os membros da Rede Cedros apresentam similaridade, com capital burocrático muito baixo e político baixo ou médio. A mesma diversidade foi constatada entre membros do Enatespo, MBRO e Rede Cedros na análise entre os capitais científico e político. Quanto àqueles da Aboprev que eram consultores do Ministério da Saúde observou-se nova semelhança, com alto capital científico e político mediano.

Observou-se que o grupo dos dentistas que sempre se posicionou como contrário à fluoretação do sal e participava de movimentos críticos quanto à política, apresentava trajetória ascendente e concepção de SUS democrático, conforme classificação elaborada por Paim (2009). A maioria destes teve trajetória ligada à saúde pública através da formação pós-graduada ou experiência no serviço público. Já no grupo que foi favorável à política, inicialmente, ou mostrou neutralidade inicial e depois apresentou tomada de posição contrária à fluoretação do sal, muitos apresentaram concepções referentes ao SUS formal com o sentido de trajetória estável e origem de classe média. O entrevistado que foi favorável à política desde o início, defendendo sua implementação no nível nacional em locais selecionados, 
apresentou concepção de SUS formal, trajetória estável com ponto de partida de classe média.

A posição na fratria, o local onde cursou o segundo grau e a macrorregião de nascimento não apresentou distinções entre os grupos. Os indivíduos que participaram ou influenciaram a formulação das políticas de 1990 a 1993 eram nascidos no Nordeste, Sudeste ou Sul. Conforme já referido, todos os dentistas que participaram dos movimentos ou eventos de críticas à política haviam participado do movimento estudantil. Já o entrevistado favorável à política não apresentou a referida participação. No grupo da Aboprev, com publicações iniciais favoráveis à política, mas críticas severas após análise e tomadas de posição contrária, não existiu homogeneidade.

No sociograma, representa-se os agentes segundo tomadas de posição e capital político. Encontram-se à direita, aqueles favoráveis à fluoretação do sal de cozinha, inclusive algumas entidades de classe, como a ABO e o CFO, além da Rede Cedros. À esquerda, em posição contrária, localizou-se o grupo dos movimentos de crítica, como Enatespo e Cebes. Ao centro, estão representados a DNSB e os consultores da Aboprev que, inicialmente, se manifestaram como neutros, mas depois se declararam contrários (Figura 14).

Através das análises das mil palavras mais frequentes com cinco, seis, sete, nove, dez e onze letras nas entrevistas realizadas, foi possível observar, novamente, uma predominância da palavra "saúde", com frequência maior que oral ou bucal. Em contraposição, aparece em, praticamente, todos os diagramas dente, dentista, odontológico, revelando a ênfase no dente. Em seguida, nas palavras com seis e sete letras aparecem procedimentos e fluoretação, o que pode corresponder, por um lado, à introdução dessa nova categoria - procedimentos coletivos, e, por outro, refletir a polêmica existente sobre a fluoretação naquele momento. Nomes como Sérgio Weyne, então coordenador, no início da década de 1990, Vitor Gomes Pinto, coordenador até 1989, e Paulo Capel Narvai, do MBRO e Enatespo, aparecem em segundo plano. Aboprev, biofilme, flúor, restauração, prevenção, criança, cariosa, desmineralização e remineralização deram conta de uma parte das propostas de origem escandinava defendidas pela Aboprev e na nova política também aparecem em segundo plano, mas também são consistentes com os debates acima analisados (Figura 15).

Outra palavra muito proferida pelos entrevistados foi Odontologia, apesar do termo saúde bucal já estar em uso nesse período. Isso pode estar relacionado à opção teórica da Aboprev de Odontologia Preventiva que norteou as ações da DNSB da época. 


\section{Quadro 13 - Entrevistado, concepção do SUS, origem social, sentido da trajetória, colégio secundário, macrorregião de nascimento, participação em movimento estudantil}

\begin{tabular}{|c|c|c|c|c|c|c|c|}
\hline E & $\begin{array}{c}\text { Tomada } \\
\text { de posição }\end{array}$ & Concepção SUS & $\begin{array}{c}\text { Origem } \\
\text { social }\end{array}$ & $\begin{array}{c}\text { Sentido da } \\
\text { trajetória }\end{array}$ & $\begin{array}{c}\text { Colégio } \\
\text { secundário }\end{array}$ & Região & $\begin{array}{c}\text { Movimento } \\
\text { estudantil }\end{array}$ \\
\hline 23 & Contra & SUS democrático & Popular & Ascendente & Público & Nordeste & Não \\
\hline 20 & Contra & SUS democrático & Popular & Ascendente & Privado & Sudeste & Sim \\
\hline 19 & Contra & SUS democrático & Popular & Ascendente & Público & Sul & Sim \\
\hline 10 & Contra & SUS democrático & Popular & Ascendente & Público & Sul & Sim \\
\hline 9 & Contra & SUS formal & Popular & Ascendente & Público & Sul & Sim \\
\hline 7 & Contra & SUS democrático & Popular & Ascendente & Privado & Sudeste & Sim \\
\hline 4 & Contra & SUS democrático & Popular & Ascendente & Público & Sul & Sim \\
\hline 3 & Contra & SUS democrático & Popular & Ascendente & Público & Sudeste & Sim \\
\hline 1 & Contra & SUS formal & Popular & Ascendente & SI & Sul & Não \\
\hline 21 & A favor & SUS formal & Média & Estável & Privado & Nordeste & Não \\
\hline 16 & $\begin{array}{l}\text { Neutro/ } \\
\text { contra* }\end{array}$ & SUS formal & Média & Estável & Público & Nordeste & Sim \\
\hline 15 & Contra & SUS democrático & Média & Estável & Público & Sul & SI \\
\hline 14 & $\begin{array}{l}\text { Neutro/ } \\
\text { contra* }\end{array}$ & SUS formal & Média & Estável & Privado & Nordeste & Não \\
\hline
\end{tabular}

* Inicialmente neutros, mas após contrários

Fonte: elaborado pela autora.

Figura 14 - Sociograma referente ao espaço de formulação das políticas de saúde bucal, início da década de 1990

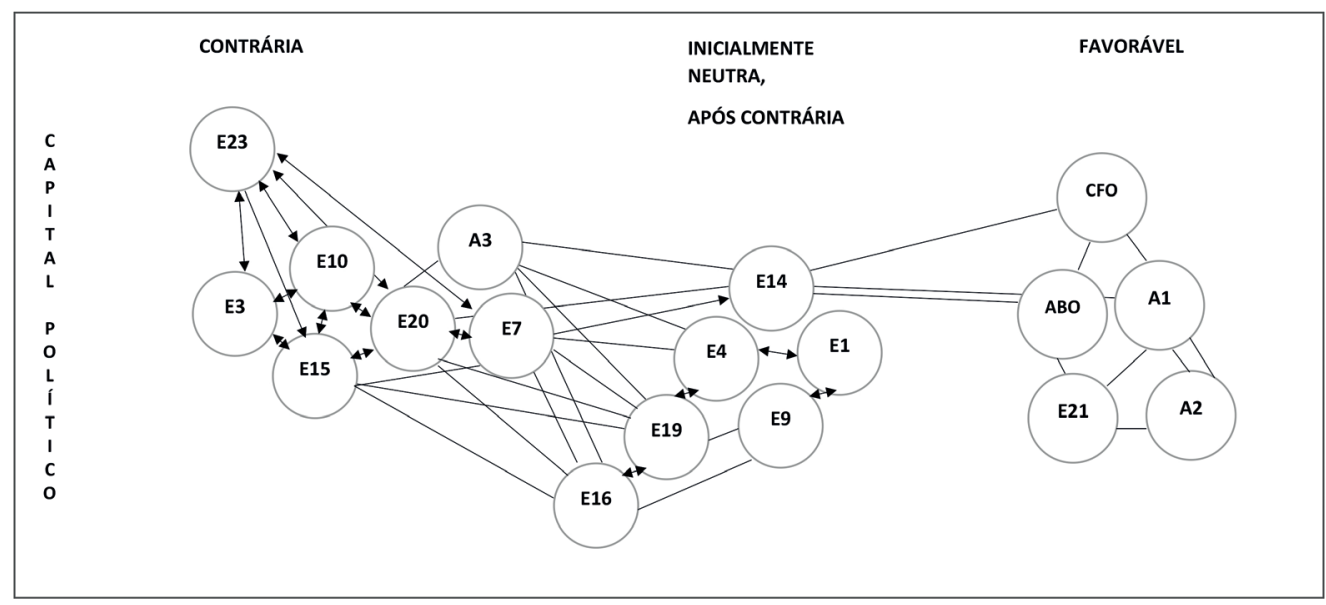

Fonte: elaborado pela autora. 
Figura 15 - Palavras mais frequentes a partir de cinco, seis, sete, nove, dez e onze letras
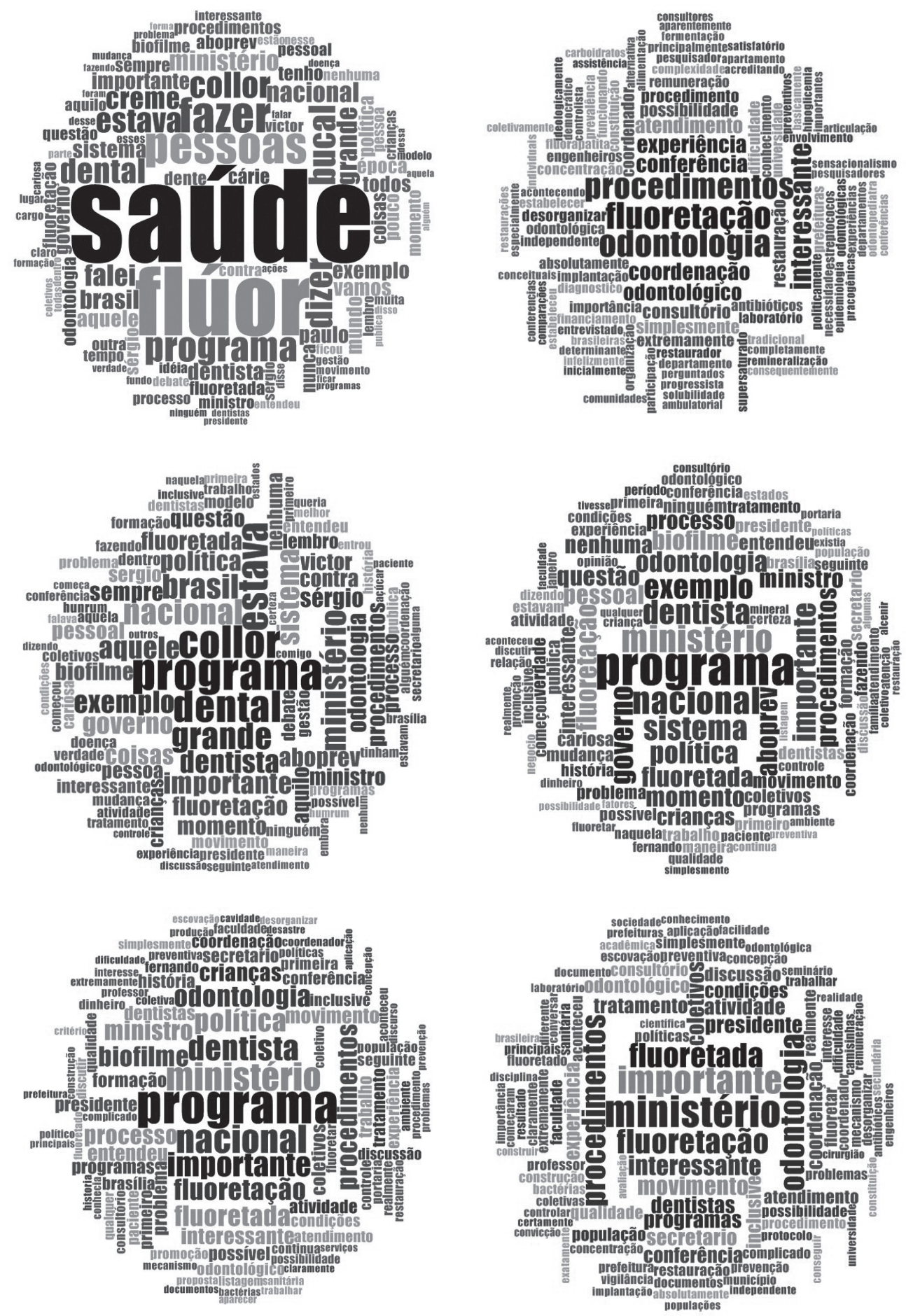

Fonte: elaborado pela autora. 


\section{Procedimentos coletivos no decorrer da década de 1990}

Conforme referido no capítulo anterior, a cirurgiã-dentista Sônia Maria Dantas de Souza assumiu a coordenação de saúde bucal, em setembro de 1995. Após José Carlos Cativo Gedeão ter deixado o cargo, o setor permaneceu sem uma liderança por alguns meses. Em entrevista, Sonia Dantas ${ }^{81}$ explicou que o convite para a vinda ao Ministério da Saúde (MS) foi feito pelo dr. Gerson Oliveira Penna $^{82}$ que foi assessor do ministro Adib Jatene. Para assumir a coordenação de saúde bucal, o convite foi feito pela dra. Neide Glória Garrido, secretária de Assistência à Saúde do Ministério da Saúde, com a aquiescência de Gerson Penna.

Quando assumiu a coordenação de Saúde Bucal, Sônia Dantas ${ }^{83}$ sofreu preconceito por ser mulher em uma profissão eminentemente masculina. Oriunda do Norte do país, em cargo, anteriormente, apenas ocupado por homens com reconhecimento científico ou burocrático, a então coordenadora nacional não pertencia ao campo científico, possuía especialização em Saúde Pública e construiu sua carreira no campo burocrático no estado do Pará, ou seja, as diferenças dos dentistas que ocuparam o cargo anteriormente eram de gênero, região e capital científico, bem como não apresentavam o acúmulo de capital simbólico daqueles que a antecederam. Havia também a oposição técnico x político na qual a profissional

81 Sonia Maria Dantas de Souza, entrevista concedida à autora, Brasília, 2014.

82 Gerson Oliveira Penna é graduado em Medicina pela Universidade Federal do Pará (UFPA) (1984). Titulado como especialista em Dermatologia pela Sociedade Brasileira de Dermatologia/AMB (1988), especialista em Planejamento Estratégico (1992), doutor em Medicina Tropical, pela UnB (2002). Vice-presidente eleito da Sociedade Brasileira de Dermatologia e presidente do Congresso Brasileiro de Dermatologia (2006). Fundador e ex-diretor do Centro Nacional de Epidemiologia do Ministério da Saúde. Foi assessor especial do ministro Adib Jatene, consultor da Organização Pan-Americana da Saúde, consultor da Organização Mundial da Saúde (OMS) e consultor do Programa das Nações Unidas para o Desenvolvimento. É do Editorial Board do Leprosy Review, único periódico indexado sobre o assunto no Med Line. Foi secretário de Estado de Vigilância em Saúde do Ministério da Saúde e presidente do Conselho Consultivo da Agência Nacional de Vigilância Sanitária. Médico e pesquisador colaborador pleno do Núcleo de Medicina Tropical, da UnB e pesquisador associado do Centro de Referência Nacional em Dermatologia (Fortaleza - CE). Investigador Principal do Ensaio Clínico Randomizado, estudo independente para determinar a efetividade do esquema Uniforme de MDT de seis doses (U-MDT) em pacientes de hanseníase (U-MDT/RCT-BR), financiado pelo Departamento de Ciência e Tecnologia (Decit) do Conselho Nacional de Desenvolvimento Científico e Tecnológico (CNPq). Pós-doutorando no Instituto de Saúde Coletiva da Universidade Federal da Bahia (ISC/UFBA).

83 Como a cirurgiã-dentista veio ao Ministério da Saúde inicialmente para assumir outro cargo, a Portaria $n^{\circ}$ 1669, de 25 de agosto de 1995, publicada no DOU, de 28 de agosto de 1995, nomeava Sonia Maria Dantas de Souza para exercer cargo em comissão de coordenadora da Coordenação Geral de Atenção a Grupos Populacionais e Atividades Sistêmicas. Apesar de ter assumido a coordenação de saúde bucal neste período, não foram encontradas portarias no diário oficial atualizando sua lotação em 1995. 
se situava no campo técnico, característica do campo burocrático, que corresponde ao desinteresse material ou político e o interesse no universal, no público, ou seja, com o SUS, com a saúde pública.

A estrutura da Coordenação Nacional de Saúde Bucal da Secretaria de Projetos Especiais se manteve a mesma da DNSB: dois técnicos que vinham participando desde o GT-Odonto, Mércio de Azevedo Ferreira e Benedito Elias Waquim, uma secretária e a coordenadora. Apesar de o entrevistado afirmar que as políticas anteriores foram utilizadas, os documentos anteriores permaneceram como projetos distantes. A coordenação da segunda metade da década de 1990 tinha como meta uma nova redação para a política nacional, entretanto, esta não foi concretizada. Os documentos da II CNSB e dos Enatespo foram mencionados como norteadores das ações.

Os PC passaram por revisões contínuas. Estudo realizado em 1995, pela Coordenação, que analisou os procedimentos coletivos no segundo semestre de 1994 e no primeiro semestre de 1995, apontou baixa cobertura populacional, falta de registro, aumento exagerado de determinados procedimentos em relação ao mês anterior e Unidades Federadas que realizavam pouquíssimos PC. (BRASIL, 1995) Neste documento, recomendava-se apresentar a situação nas reuniões das Comissões Intergestores Bipartite (CIB), no sentido de minimizar os problemas encontrados, oferecer instrumentos às coordenações estaduais, apoiar os estados a apresentarem melhor desempenho e definirem o encaminhamento da produção mensal à coordenação nacional. (BRASIL, 1995)

No trabalho citado, verificou-se disparidades na quantidade de recursos recebida pelos estados. Destaca-se as grandes quantias recebidas pelos estados de Pernambuco, Mato Grosso do Sul, Minas Gerais, São Paulo, Paraná e Santa Catarina, no segundo semestre de 1994 e 1995 . Essas análises ficavam a cargo do comitê de especialistas voltadas para o Sistema de Informação. Um dos dentistas que integrava esta parte do Comitê foi João Antônio Neto Caminha. ${ }^{84}$

Os PC II e III foram excluídos da tabela de procedimentos SIA/SUS, ${ }^{85} \mathrm{em} 1997$, sendo concatenados em apenas um procedimento coletivo. Em portaria ${ }^{86}$ subsequente, da Secretaria de Assistência à Saúde, os PC aparecem unificados, inte-

84 João Antônio Neto Caminha é cirurgião-dentista, possui mestrado em Odontologia pela UFRGS (1981). Foi diretor-presidente do Fundação de Apoio à UFRGS. Tem experiência na área de Odontologia, com ênfase em Odontologia Social e Preventiva - informações extraídas do currículo Lattes.

85 Portaria MS/GM n 1.889, de 18 de dezembro de 1997, publicada no DOU, de 22 de dezembro de 1997.

Portaria $n^{\circ} 166$, de 31 de dezembro de 1997, publicada no DOU, de 20 de janeiro de 1998. 
grando o Piso da Atenção Básica (PAB) como um "conjunto de procedimentos de promoção e prevenção em saúde bucal, de baixa complexidade, dispensando equipamentos odontológicos, desenvolvidos integralmente em grupos populacionais previamente identificados”. (BRASIL, 1998)

Outra justificativa para as modificações no PC foram visitas realizadas pela coordenadora de saúde bucal e sua equipe aos municípios, onde foi percebido que o levantamento epidemiológico não era realizado, mas todos recebiam como se tivesse sido feito. Ela e a equipe constatavam que o procedimento mais realizado eram as escovações supervisionadas, entretanto, sem controle da periodicidade e na distribuição das escovas e dentifrícios. Assim, a unificação dos PC visava minimizar essas distorções. 